\title{
Management of the investment activities of the mining industry
}

\author{
Liliia Filipishyna ${ }^{1}$, Natalia Mihai ${ }^{1}$, Ihor Tarasov ${ }^{1}$, Mykola Andriienko ${ }^{2 *}$, and I Wayan Edi \\ Arsawan $^{3}$ \\ ${ }^{1}$ Pervomaisk Branch of the Admiral Makarov National University of Shipbuilding, 107 Odeska St., \\ 55200 Pervomaisk, Ukraine \\ ${ }^{2}$ Interregional Academy of Personnel Management, 2 Frometivska St., 03039 Kyiv, Ukraine \\ ${ }^{3}$ Bali State Polytechnic, Jl. Raya Uluwatu No. 45, Jimbaran, Kec. Kuta Sel., Kabupaten Badung, \\ 80361 Bali, Indonesia
}

\begin{abstract}
The paper studies the main directions of investment activities of mining enterprises within the framework of the industrial development program. The principles of investment activities of mining enterprises have been substantiated, which are correlated with the priorities of socioeconomic development and tools for stimulating investment in the mining industry. At each level of approach to investment activity management of mining enterprises, there is a link between the enterprise and the external environment to assess the investment attractiveness of investment objects and their competitive advantages. Competitive advantages have been revealed, which are largely determined by the direction of investment activities of mining enterprises as a result of direct investment, on the one hand, and the role of investment activities in increasing the competitive advantages of the mining industry. Taking into account the risk-forming factors of the macro - and micro environment of the mining industry, the foundations of the investment processes development have been substantiated when choosing financing instruments, which provides the optimal ratio of return and investment risk for all stakeholders.
\end{abstract}

\section{Introduction}

The investment process is an integral basis for economic development not only at the micro level, but also at the meso and macro levels of the national economy. The investment process reflects the strategy of attracting capital to the real sector of the economy in order to increase investment attractiveness in all sectors, including industry, which ensures sustainable development and competitiveness of the national economy.

Enterprises of the mining complex ensure the production process in accordance with the fundamentals of a market economy, within which free prices for minerals have been introduced and, accordingly, an increase in the deregulation of the mining complex by amending the Mining Law of Ukraine regarding the simplification of the business environment.

However, there is a decrease in the efficiency of the reproduction process of the mineral

\footnotetext{
* Corresponding author: Andnv@ukr.net
} 
resource base of the mining industry, the profitability of mining operations caused by the physical and moral deterioration of technological equipment, which necessitates the use of various tools for the development of mining enterprises, such as investments. The high capital intensity of mining enterprises and the return on capital investment encourage them to solve the problems of investing the projects in the enterprise and the need to update and modernize the technical potential due to the high resource and energy intensity of the industry. With regard to the mining industry, the objectives of investment activity are an increase in the proven reserves of minerals and an increase in their production.

But only with a more complete account of the risks and interests of investors, it is possible to increase the efficiency of the investment processes development when choosing financing instruments, which ensures an optimal ratio of return and investment risk for all stakeholders.

The investment activity of a mining enterprise is inextricably linked with investment policy as a component of public administration, which should be focused on increasing the investment attractiveness and attracting funds from private investors based on the further development of state regulation of prices for mineral resources and stimulating the mining industry through preferential taxation. However, attracting investments in the mining industry is complicated by its specificity conditioned by the risks and long payback periods. The purpose of the study is to substantiate the main directions of ensuring the investment activities of enterprises within the framework of the program for the resource base development of the mining industry.

\section{Literature review}

An extensive scope of literature, covering a wide range of both theoretical and practical aspects of these problems, is devoted to issues of state regulation of investments in the mining industry. Various aspects of the problem of the mining industry investment are reflected in the works on the problems of investment project management $[1-5]$. In the works [6-8], the issues of planning and analysing the efficiency of investment in the mining industry are studied. The research problems of investment activity and regional investment policy of industry are studied in the work [9-11].

\section{Material and methods}

Modern methods for assessing the investment are based on indicators for assessing the economic efficiency of the project and the return on investment. Performance criteria in the conditions of mining enterprises operation do not fully reflect the relationship between the organizational and technical level of enterprises and their investment support. Therefore, methods of managing the investment activities are used based on the theory of the life cycle and according to the functions of investment management, as well as assessing the investment opportunities of the amount of borrowed funds attracted by the enterprise to implement the investment projects. In the management of the investment activities of enterprises, the capital investment index is used, which reflects the change in the volume of capital investment and is determined as the ratio of the value of assets in which funds are invested for periods taking into account the price index (deflator). For most mining companies, it is necessary to improve the methods of making investment decisions and their financial support.

\section{Results and discussion}

The mining industry is of strategic importance for the national economy, the efficiency of which directly affects the rate of industrial growth. However, with the decline in the 
production and the growing costs of the mining industry, investments in modern mining and exploration technologies are required, which imposes increased requirements to the quality of the investment activities management in the mining industry. Investment activity at the industrial enterprise is the process of accumulating funds and providing financial support for the movement and reproduction of capital. In the context of limited financial resources of the mining enterprises, the emphasis is on the development of improving the validity of investment policy and investment activities management in order to improve its quality to reduce investment risks and develop the production base of mining enterprises.

\subsection{Analysis of production dynamics and conditions for the development of investment activities of mining enterprises}

The state balance of mineral reserves of Ukraine has identified about 9000 deposits of industrial importance (Fig. 1), from which these are reserves of coal, iron ore, graphite, etc. However, the reproduction of the mineral resource base does not meet modern needs through low financing of geological exploration work, which reduces their production.
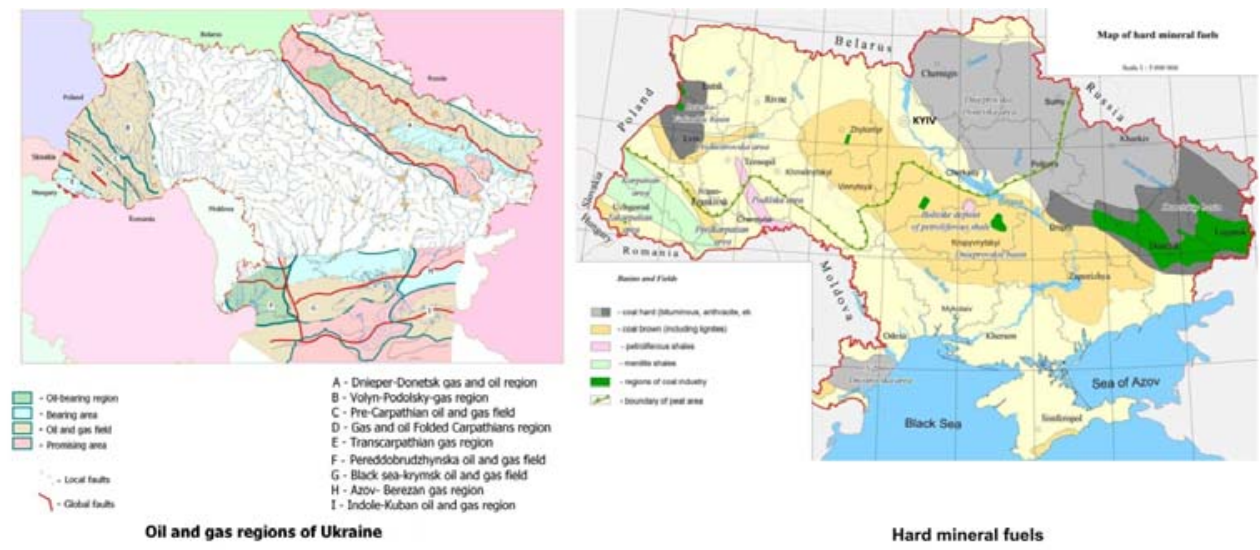

Fig. 1. Map of the combustible mineral deposits distribution [12].

The decline in business activity and investment attractiveness in Ukraine encourages industrial enterprises to improve their production activity, as well as to form and implement investment policies that would meet modern challenges and achievements of scientific and technological progress. In the context of reducing the resource base of the mining industry, it is necessary to use innovative technologies for increasing the capital return of minerals, to stabilize and increase production in the industry. The stabilization and improvement of the mining industry efficiency depend on its structural changes in the national economy. Against the background of improving business expectations and reducing investment risks, starting from 2017, investment activities of industrial enterprises have been promoted, which is associated with their development of production activities and a decrease in unprofitable economic activities in the mining industry, which amounted to $47.8 \%$ in 2014 and $36.8 \%$ in 2019 (Fig. 2.).

The volume of sold products of the mining industry in 2019, which amounted to $13.4 \%$ as part of industrial products, has increased by 3318 million UAH compared to 2018 to 394789.1 million UAH and showed a stable trend since 2015 [13]. Assessing the economy development in the mining industry, it can be concluded that the activities of mining enterprises have formed a stable system of economic interaction with other industries. 


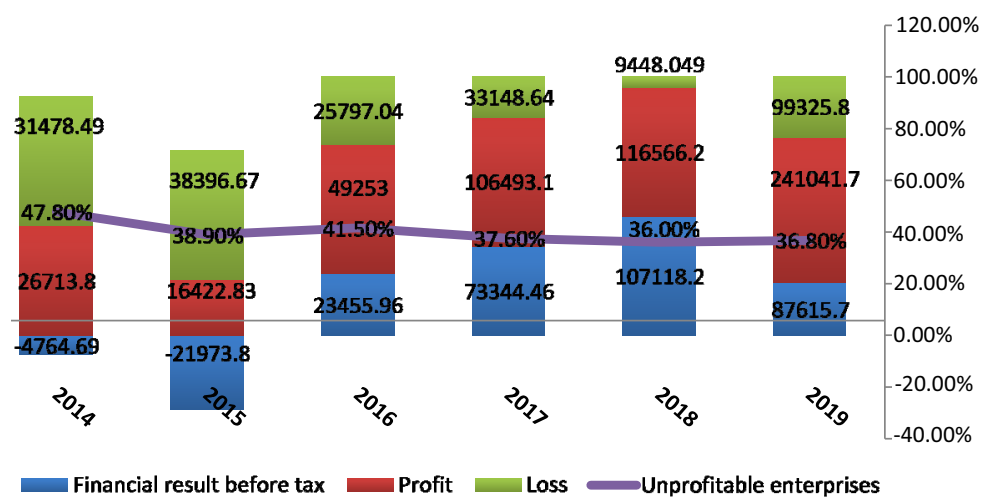

Fig. 2. Financial results of enterprises of the oil and gas industry for 2014-2019, million UAH [13].

Investment activity of mining enterprises involves attracting investment resources to increase not only income, but also to strengthen economic potential and competitiveness, taking into account the industry-specific features of financing the investment process.

The number of unprofitable industrial and mining enterprises is $38 \%$ on average, which is confirmed by the deterioration of financial results and the fall in investment, which is mainly financed from the enterprises' own funds [29]. The key problem is to retain employees at unprofitable enterprises, which are forced to reduce their staff to support their financial security. In $2014-2015$, the loss of mining enterprises significantly exceeded the profit, which is associated with changes in market conditions and sales markets.

The share of the mining enterprises is unprofitable, which requires the support of stateowned enterprises as part of natural monopolies that reduce economic growth. This requires the use of measures aimed at restructuring and reducing the cost of production through effective tax policy and state regulation of prices [14, 16-20].

Search for the priority areas of investment activity and their implementation determine the development of a system for making management decisions aimed at raising funds and increasing capitalization. The formation of an investment management system should take into account the interests of all stakeholders and include the following levels (Fig. 3).

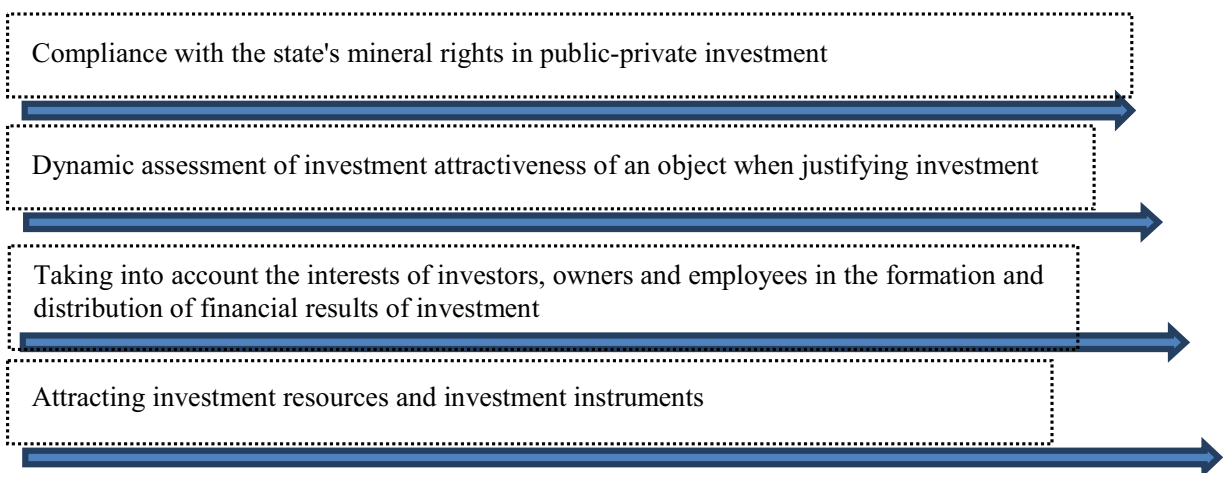

Fig. 3. Approach to the investment activities management of mining enterprises.

The investment activities management of the enterprise is based on the peculiarities of the investment environment in the mining industry: material intensity, duration of investment projects implementation. At each level of the approach to the investment activities management of mining enterprises, there is a link between the enterprise and the 
external environment to assess the investment attractiveness of investment objects and their competitive advantages [21 - 24].

To assess the investment opportunities, the amount of borrowed funds attracted by the enterprise for the investment projects implementation is taken into account:

$$
I_{t}=P+A+D C
$$

where $P$ is the net profit of the enterprise; $A$ is depreciation; $D C$ is the amount of borrowed funds.

The volume of investments in the development of mining industry is increasing every year from $26 \%$ to $58 \%$ (Table 1), but the return has increased to a much lesser extent, and general state of wear has not improved. This is conditioned by a reduction in the investment volumes in fixed assets and the commissioning of fixed assets.

Table 1. Capital investment and indices of capital investment of mining enterprises.

\begin{tabular}{|l|c|c|c|c|c|c|c|c|}
\hline & \multicolumn{2}{|c|}{$\mathbf{2 0 1 6}$} & \multicolumn{2}{c|}{$\mathbf{2 0 1 7}$} & \multicolumn{2}{c|}{$\mathbf{2 0 1 8}$} & \multicolumn{2}{c|}{$\mathbf{2 0 1 9}$} \\
\cline { 2 - 9 } & Volume & $\begin{array}{c}\text { Index / } \\
\text { Increase }\end{array}$ & Volume & $\begin{array}{c}\text { Index / } \\
\text { Increase }\end{array}$ & Volume & $\begin{array}{c}\text { Index / } \\
\text { Increase }\end{array}$ & Volume & $\begin{array}{c}\text { Index / } \\
\text { Increase }\end{array}$ \\
\hline \multirow{2}{*}{ Industry } & $\begin{array}{c}108635.2 \\
\text { million } \\
\text { UAH }\end{array}$ & $\begin{array}{c}118.7 \% / \\
29.1 \%\end{array}$ & $\begin{array}{c}136490.1 \\
\text { million } \\
\text { UAH }\end{array}$ & $\begin{array}{c}123.4 \% / \\
25.6 \%\end{array}$ & $\begin{array}{c}179718.3 \\
\text { million } \\
\text { UAH }\end{array}$ & $\begin{array}{c}122.2 \% / \\
31.6 \%\end{array}$ & $\begin{array}{c}231849.5 \\
\text { million } \\
\text { UAH }\end{array}$ & $\begin{array}{c}134.7 \% / \\
29 \%\end{array}$ \\
\hline $\begin{array}{l}\text { Mining } \\
\text { and } \\
\text { quarrying }\end{array}$ & $\begin{array}{c}21740.0 \\
\text { million }\end{array}$ & $\begin{array}{c}115.6 \% / \\
26 \%\end{array}$ & $\begin{array}{c}34436.0 \\
\text { million } \\
\text { UAH }\end{array}$ & $\begin{array}{c}151.4 \% / \\
58.3 \%\end{array}$ & $\begin{array}{c}52848.1 \\
\text { million } \\
\text { UAH }\end{array}$ & $\begin{array}{c}141.5 \% / \\
53.4 \%\end{array}$ & $\begin{array}{c}67747.2 \\
\text { million } \\
\text { UAH }\end{array}$ & $\begin{array}{c}138.1 \% / \\
28.1 \%\end{array}$ \\
\hline
\end{tabular}

The capital investment index reflects changes in the volume of capital investment and is defined as the ratio of the assets value in which funds have been invested over the periods, taking into account the price index (deflator) and is calculated using the formula [13]:

$$
I_{t / b}=\frac{\sum_{j}\left(v_{j t} \div i_{j t / b}\right)}{\sum_{j} \bar{v}_{j b}},
$$

where $t$ is the reported quarter, $y$ is the reported year; $b$ is base year; $j$ is type of assets; $m$ is number of asset types involved in the calculation; $v_{j t}$ is the volume of capital investment by type of asset $j$ in quarter $t$; $i_{j t / b}$ is price index of capital investment by type of asset $j$ in quarter $t$ to quarterly average value of the base year $b ; \bar{v}_{j b}$ is quarterly average volume of capital investment by type of asset $j$ in the base year.

Investment management of the enterprise is based on financial provision of investment process, which includes a stage of analyzing the investment state with assessing the necessary volume of the enterprise resources. It is the analysis of the investment state that provides for the determination of future development prospects, in addition to reflecting the state of investment activity development. In such conditions, the determination of the investment volume, for example, in the renewal of production assets, is possible by calculating the achievement of the possible return on capital and income from sales, which in the ratio between these indicators would show whether there is an intensive or extensive renewal $[25,29]$.

It is important to note the increasing relevance of venture capital in the investment support of industrial enterprises, as regards high-risk projects in comparison with other sources of investment. World practice evidences an increase in the volume of venture investment by medium-sized enterprises, which corresponds to the acceleration and not significant growth rates of venture funds. The main restraining factors for the development 
of venture investment are the weak investment attractiveness of the industry and the outflow of capital abroad. These conditions should stimulate the improvement of state regulation of venture investment with the aim of enhancing investment activity both in industry and in the national economy.

\subsection{Provision of investment activities for enterprises in the mining industry}

The decline in the production volumes in the industry has led to the need of increasing investment in the activities of industrial enterprises. Investment in industry averaged 10$12 \%$ of the total structure for $2017-2019$, which is insufficient for the industry and its branches modernization. The main factors that reduce investment in industry are high risk and insufficient funds of domestic investors.

In conditions of a shortage of investment sources for mining enterprises, there is a need to develop an effective mechanism for managing the process of resource provision based on attracting investment, which requires an assessment of investment risks at the level of not only enterprises, but also the determination of ways to manage the investment process by all stakeholders, including the state. Risks in the mining industry limit the possibilities of attracting capital and affect the degree of risk appetite of investors when choosing financing instruments.

Investment activities of mining enterprises are implemented mainly at the expense of the own sources of the enterprise funds, but in the conditions of growing inflation, they significantly constrain the reproduction of fixed assets. In these conditions, the investment activity of mining enterprises is based only on depreciation as the main source of their own investment resources.

Table 2. The producer price indices for industrial products in January-December 2016 - 2019* (to the corresponding period of the previous year), $\%$

\begin{tabular}{|l|c|c|c|c|}
\hline & 2016 & 2017 & 2018 & 2019 \\
\hline Industry & 121.2 & 136.8 & 117.4 & 104.1 \\
\hline Mining and quarrying & 112.7 & 209.1 & 118.2 & 103.7 \\
\hline hence: & & & & \\
Extraction of coal & 103.5 & 143.5 & 121.6 & 99.1 \\
\hline Production of crude oil and natural gas & 189.4 & 223.8 & 116.0 & 97.2 \\
\hline Mining of iron ores & 88.8 & 235.2 & $\mathbf{1 1 7 . 4}$ & 108.9 \\
\hline
\end{tabular}

*Source: Industrial producer price indices [13].

The rapid growth of inflation in the mining industry was observed in 2017 and amounted to $209.1 \%$, and in its structure, $235.2 \%$ of inflation was "Iron ore mining". In modern conditions, the investment activity of mining enterprises is characterized by low investment activity and investment attractiveness [13].

In response to high inflation, which is holding back returns on investment, enterprises invest in imported equipment and financial assets as part of investment management. Selffinancing as the main source of investment resources does not contribute to further technological and technical renewal in the mining industry, therefore, a system of measures is needed to enhance the role of banking instruments: lending, leasing, etc. [26, 30].

In addition to the high level of inflation, high taxes and high investment risks act as restraining barriers. When comparing the sectors of the economy in terms of tax revenues in the mining industry, the share was $20-25 \%$ in $2017-2019[13,30]$. 
The process of managing investment activity at the enterprise includes an analysis of the market situation and the choice of financing sources. In addition, in the context of permanent crisis situations in the world economy and Ukraine, the share of budget allocations for the enterprises development in the mining industry has decreased and the share of enterprises' own funds has increased. The main directions for improving the investment activities management in the mining industry are:

- integration into global added value chains, expanding the geography of product sales in the foreign market and diversification of production;

- improving the investment climate through the revision of regulatory processes and government support for expansion of access to financial resources including through government funding;

- active use of public-private partnerships and concessions to attract public and private investment;

- digitalization of industry with the use of advanced information technologies.

Public-private partnership is the basis for restoring investment activity, especially of state-owned mining enterprises, which determines the use of program-oriented methods for regulating investment activities, which will determine the priority direction of investment to ensure the sustainability of the enterprise in the strategic perspective [27, 28, 31].

The issue of bonds plays an important role in ensuring the investment activity of mining enterprises, and in the conditions of worsening the environmental component in the industry, the issue of "green" bonds is relevant [32]. It is through investment that the environmental standards of production at mining enterprises can be met, which contribute to the organization of rational environmental management.

Stimulation of investment in fixed assets in the mining industry should be associated with reducing the tax burden on enterprises in the real sector of the economy, ensuring the innovation of investment projects. Updating of fixed assets due to technical re-equipment is one of the priority tasks of investment management [33-35].

Therefore, in order to increase the efficiency of return on investment in the mining industry, it is advisable to rationalize the profit generation structures, mainly related to the resale of finished products rather than production. In addition, due to low-tech production and dominance in the structure of producing the goods with low added value, there is no modernization and growth of industrial production.

\section{Conclusions}

Mining industry is the basis of economic development, the dynamics of which have become a reflection of the general state of the national economy, which encourages the acceleration of qualitative structural changes and attracting investment in the real sector of the economy.

Investment activity at the industrial enterprise is the process of accumulating funds and providing financial support for the movement and reproduction of capital. The key reason for the low investment efficiency of mining enterprises is that their investment policy is aimed at extensive exploitation of mineral deposits with the orientation of those investment projects that have a short payback period. The growth of investment activity in industry contributes to the improvement of the financial state of enterprises and actualizes the provision of real investment, which is associated with the multiplicative effect of the national economy growth.

Management of investment activities of mining enterprises contributes to improving the reproduction process and the efficiency of production and competitiveness of the product produced, especially in the context of economic reforms, thereby contributing to the sustainable economy development. 
To ensure investment management, managers should take into account the specific nature of the mining industry. It is necessary to create favorable conditions for attracting private investment for further high-tech production.

The authors gratefully acknowledge financial support from the Admiral Makarov National University of Shipbuilding.

\section{References}

1. Alfaro, L., \& Charlton, A. (2009). Intra-industry foreign direct investment. American Economic Review, 99(5), 2096-2119. https://doi.org/10.1023/10.1257/aer.99.5.2096

2. Bilotserkivets, V.V., \& Zavhorodnia, O.O. (2017). Innovative challenges and post-crisis prospects of Ukrainian mining and metallurgical industry. Naukovyi Visnyk Natsionalnoho Hirnychoho Universytetu, (2), 149-156.

3. Crouzet, N., \& Eberly, J. C. (2019). Understanding weak capital investment: The role of market concentration and intangibles (No. w25869). National Bureau of Economic Research.

4. Dembinski, P.H., Bonvin, J.M., Dommen, E., \& Monnet, F.M. (2003). The ethical foundations of responsible investment. Journal of Business Ethics, 48(2), 203-213. https://doi.org/10.1023/B:BUSI.0000004598.89426.d8

5. Erdilek, A. (Ed.). (2019). Multinationals as mutual invaders: intra-industry direct foreign investment. Routledge.

6. Espinoza, R.D., \& Rojo, J. (2017). Towards sustainable mining (Part I): Valuing investment opportunities in the mining sector. Resources Policy, (52), 7-18. https://doi.org/10.1016/j.resourpol.2017.01.011

7. Gupta, A.K., \& Sapienza, H.J. (1992). Determinants of venture capital firms' preferences regarding the industry diversity and geographic scope of their investments. Journal of Business Venturing, 7(5), 347-362. https://doi.org/10.1016/0883-9026(92)90012-G

8. Jenner, K., Walker, A., Close, C., \& Saunders, T. (2018). Mining Investment Beyond the Boom. RBA Bulletin (March), 1-15.

9. Matyjaszek, M., Wodarski, K., Krzemień, A., García-Miranda, C.E., \& Sánchez, A.S. (2018). Coking coal mining investment: Boosting European Union's raw materials initiative. Resources Policy, (57), 88-97. https://doi.org/10.1016/j.resourpol.2018.01.012

10. Solianik, L.G. (2014). Problems of improvement of investment activity management at enterprises of mining-metallurgical complex of Ukraine. Economic Bulletin of the National Mining University, 46(46), 44-54.

11. Pivnyak, G., Bondarenko, V., Kovalevs'ka, I., \& Illiashov, M. (Eds.). (2013). Mining of Mineral Deposits. London, United Kingdom: CRC Press, Taylor \& Francis Group. https://doi.org/10.1201/b16354

12. Mineral resources of Ukraine. (2020). Retrieved from: http://minerals-ua.info/

13. Enviromental of Ukraine. (2019). Retrieved from: http://ukrstat.gov.ua

14. Code of Ukraine on subsoil. (2019). Retrieved from: http://rada.gov.ua

15. Excerpt from the State Register of Investment Projectsb. (2019). Retrieved from: http://me.gov.ua

16. Kostetska, K., Khumarova, N., Umanska, Y., \& Shmygol, N., \& Koval, V. (2020). Institutional qualities of inclusive environmental management in sustainable economic development. Management Systems in Production Engineering, 28(2), 15-22. https://doi.org/10.2478/mspe2020-0003

17. UN Environment Programme (2017). The Green Economy Progress Measurement Framework. Retrieved from: https://www.un-page.org/green-economy-progress-measurement-framework

18. Koval, V., Mikhno, I., Hajduga, G., \& Gaska, K. (2019). Economic efficiency of biogas generation from food product waste. E3S Web Conferences, (100), 00039. https://dx.doi.org/10.1051/e3sconf/201910000039 
19. Baklanova, O., Petrova, M., \& Koval, V. (2020). Institutional Transmission in Economic Development. Ikonomicheski Izsledvania, 29(1), 68-91.

20. Pivnyak, G., Bondarenko, V., \& Kovalevska, I. (Eds.). (2015). New Developments in Mining Engineering 2015. London, United Kingdom: CRC Press, Taylor \& Francis Group. https://doi.org/10.1201/b19901

21. Koval, V., Mikhno, I., Trokhymets, O., Kustrich, L., \& Vdovenko, N. (2020). Modeling the interaction between environment and the economy considering the impact on ecosystem. E3S Web Conferences, (166), 13002. https://doi.org/10.1051/e3sconf/202016613002

22. Koval, V., Mikhno, I., Trokhymets, O., Kustrich, L., \& Vdovenko, N. (2020). Modeling the interaction between environment and the economy considering the impact on ecosystem. E3S Web Conferences, (166), 13002. https://doi.org/10.1051/e3sconf/202016613002

23. Koval, V., Sribna, Y., Mykolenko, O., \& Vdovenko, N. (2019). Environmental concept of energy security solutions of local communities based on energy logistics. 19th International Multidisciplinary Scientific GeoConference SGEM 2019, Ecology, Economics, Education and Legislation, 283-290. https://doi.org/10.5593/sgem2019/5.3/S21.036

24. Nazarova, K., Mysiuk, V., Gordopolov, V., Koval, V., \& Danilevičienė, I. (2020). Preventional audit: implementation of SOX control to prevent fraud. Business: Theory and Practice, 21(1), 293-301. https://doi.org/10.3846/btp.2020.11647

25. Petrova, M., Koval, V., Tepavicharova, M., Zerkal, A., Radchenko, A., \& Bondarchuk, N. (2020). The interaction between the human resources motivation and the commitment to the organization. Journal of Security and Sustainability Issues, 9(3), 897-907. https://doi.org/10.9770/jssi.2020.9.3(15)

26. Shmygol, N., Galtsova, O., Solovyov, O., Koval, V., \& Arsawan, I. (2020). Analysis of country's competitiveness factors based on inter-state rating comparisons. E3S Web Conferences, (153), 03001. https://doi.org//10.1051/e3sconf/202015303001

27. Yankovyi, O., Goncharov, Yu., Koval, V., \& Lositska, T. (2019). Optimization of the capitallabor ratio on the basis of production functions in the economic model of production. Naukovyi Visnyk Natsionalnoho Hirnychoho Universytetu, (4), 134-140.

28. Yeshchenko, M., Koval, V., \& Tsvirko, O. (2019). Economic policy priorities of the income regulation. Espacios, 40(38), 11.

29. Filipishyna, L., Bessonova, S., \& Venckeviciute, G. (2018). Integral assessment of developmental stability: cases of Lithuania and Ukraine. Entrepreneurship and Sustainability Issues, 6(1), 87-99. https://doi.org/10.9770/jesi.2018.6.1(7)

30. Chorna, M., Filipishyna, L., Krutova, A., Bezghinova, L., \& Drobysheva, O. (2019). Features of the evaluation of the effectiveness of anti-crisis entrepreneurship in industry. Journal of Entrepreneurship Education, (22).

31. Romanenko, Y.O., \& Chaplay, I.V. (2016). Marketing communication system within public administration mechanisms. Actual Problems of Economics, 178(4), 69-78.

32. Holovatyi, M. (2014). Multiculturalism as a means of nations and countries interethnic unity achieving. Economic Annals-XXI, 11-12, 15-18.

33. Shvets, V.Y., Rozdobudko, E.V., \& Solomina, G.V. (2013). Aggregated methodology of multicriterion economic and ecological examination of the ecologically oriented investment projects. Naukovyi Visnyk Natsionalnoho Hirnychoho Universytetu, (3), 139-144.

34. Dobina, T., Haidukevych, K., Panchenko, S., Petrova, I., \& Sabadash, J. (2019). Effectiveness analysis of entrepreneurship model of development qualities of future managers. Journal of Entrepreneurship Education, 22(3).

35. Bakulina, O., Lehan, I., \& Bakhov, I. (2019). Cluster associations as a factor of innovative and integrative development of the economy. International Journal of Innovative Technology and Exploring Engineering, 8(10), 2249-2255. https://doi.org/doi:10.35940/ijitee.J1122.0881019 